\title{
Dietary protein quality and quantity affect lactational responses to corn distillers grains: A meta-analysis
}

\author{
M. Hollmann, M. S. Allen, and D. K. Beede ${ }^{1}$ \\ Department of Animal Science, Michigan State University, East Lansing 48824
}

\begin{abstract}
Diet fermentability influences lactational responses to feeding corn distillers grains (CDG) to dairy cows. However, some measures of diet fermentability are inherently related to the concentration and characteristics of corn-based ingredients in the ration. Corn-based feeds have poor protein quality, unable to meet the essential AA requirements of lactating cows. We conducted a meta-analysis of treatment means $(\mathrm{n}=44)$ from the scientific literature to evaluate responses in milk yield (MY) and milk true protein concentration and yield to dietary CDG. The test variable was the difference in response between the CDG diet mean and the control diet mean $(0 \% \mathrm{CDG})$ within experiment. Fixed variables were CDG concentration of the diet [\% of dietary dry matter $(\mathrm{DM})]$ and crude protein $(\mathrm{CP})$ concentration and fractions of $\mathrm{CP}$ based on origin (corn-based versus non-corn-based feeds) of control and CDG diets. Diets with CDG ranged from 4 to $42 \%$ CDG, DM basis. Noncorn-based dietary $\mathrm{CP}$ averaged $6.3 \pm 3.32 \%$ of total DM. Milk yield and milk true protein yield responses to added CDG were maximized when approximately $8.5 \%$ of the total dietary DM was non-corn-based CP. Milk yield response peaked for higher-producing cows (>30.0 kg MY/cow per day) at $4.3 \%$ dietary corn-based $\mathrm{CP}$, but decreased linearly for lower-producing cows $(<30.0 \mathrm{~kg} \mathrm{MY} /$ cow per day) as corn-based dietary CP increased. Milk true protein yield response decreased as corn-based dietary CP concentration increased but milk true protein concentration response was not decreased when CDG diets had more than $6.5 \%$ dietary non-corn-based CP. Overall, 8.5\% dietary non-cornbased CP was necessary in lactation diets to maximize lactational responses to dietary CDG. The necessity of dietary non-corn-based CP to maximize milk and milk protein yields limits the amount of dietary corn-based $\mathrm{CP}$, including that from CDG, which can be included in rations without overfeeding $\mathrm{N}$.
\end{abstract}

Received August 10, 2010.

Accepted December 22, 2010.

${ }^{1}$ Corresponding author: beede@msu.edu
Key words: protein quality, distillers grains, milk yield, lactational response

\section{INTRODUCTION}

We reported in a companion paper that measures of diet fermentability were associated with lactational responses of dairy cows to dietary corn distillers grains (CDG; Hollmann et al., 2011). However, several measures of diet fermentability, such as dietary concentrations of corn silage, starch, and corn grain, also are related to aspects of dietary protein quality, thus, partially confounding interpretation. Cows do not have a requirement for $\mathrm{CP}$ per se, but require certain amounts of dietary essential AA postruminally to maximize milk production (Clark, 1975). Therefore, diets that are formulated to meet or exceed CP recommendations can limit milk yield (MY) if one or more essential AA are postruminally deficient. According to NRC (2001), virtually all corn-based feeds typically fed to dairy cows supply less lysine (e.g., $3.0 \%$ of total CP) compared with, for example, soybean meal (6.3\% lysine). Thus, diets with abundant corn-based ingredients can be deficient in lysine when balanced to $\mathrm{CP}$ recommendations. Specifically, CDG contains $2.24 \%$ lysine of total CP (NRC, 2001), although lysine concentration may be more than $3.0 \%$, based on more recent survey data (Schingoethe et al., 2009). Consequently, partial substitution of CDG for non-corn-based protein sources likely decreases dietary lysine concentration. Effects of this deficiency include decreased milk true protein yield and concentration, and, to a lesser degree, MY (NRC, 2001). Although CP in CDG is less ruminally degraded than CP from most other common feed sources (Firkins et al., 1984), the protein fraction in corn resistant to ruminal degradation has lower lysine concentration than the fraction that is degraded (Dado, 1999). Therefore, we hypothesized that inclusion of CDG in diets with relatively more abundant other sources of corn-based protein is associated with negative responses in milk true protein concentration and yield and MY, and that substitution of CDG for feeds with better protein quality than CDG exacerbated the negative responses in milk true protein concentration and yield and MY. Our 
Table 1. Descriptive statistics of $\mathrm{CP}$ and CP-fractions in control diets (Ctrl), corn distillers grains (CDG) diets, and the difference in $\mathrm{CP}$ fraction $(\Delta ; \mathrm{CDG}$ minus $\mathrm{Ctrl})$ in experiments included in the statistical analyses of CDG on lactational performance $(\mathrm{n}=44)^{1}$

\begin{tabular}{llclcc}
\hline Variable & Diet & Mean & SD & Minimum & Maximum \\
\hline CP & Ctrl & 16.6 & 1.86 & 13.7 & 19.7 \\
& CDG & 16.8 & 1.91 & 13.7 & 21.0 \\
Non-corn-based CP & $\Delta$ & 0.21 & 0.704 & -1.30 & 3.00 \\
& Ctrl & 10.8 & 2.83 & 6.4 & 15.6 \\
Corn-based CP & CDG & 6.3 & 3.32 & 0.6 & 13.2 \\
Without CP from CDG & $\Delta$ & -4.50 & 2.402 & -10.3 & -0.0 \\
With CP from CDG & Ctrl & 5.8 & 1.23 & 3.3 & 7.7 \\
CP from CDG only & CDG & 5.2 & 1.32 & 3.1 & 8.3 \\
& CDG & 10.5 & 2.78 & 5.0 & 17.3 \\
& CDG & 5.3 & 2.73 & 1.1 & 12.4 \\
& $\Delta^{2}$ & -0.63 & 0.751 & -2.08 & 1.96 \\
\hline
\end{tabular}

${ }^{1}$ Results are reported as percent of dietary DM.

${ }^{2}$ Corn-based CP (CDG) without CP from CDG minus corn-based CP (Ctrl).

objective was to evaluate by meta-analysis, lactational performance of cows to dietary CDG, specifically addressing potential effects of dietary protein quality. Protein quality measures were based on concentrations of total dietary $\mathrm{CP}$ and on $\mathrm{CP}$ from non-corn and from corn-based feed ingredients.

\section{MATERIALS AND METHODS}

\section{Database}

The data acquisition and screening process of the scientific literature and data management are described in detail by Hollmann et al. (2011). All data were published as peer-reviewed scientific articles and include a CDG diet (>4.0\% CDG, dry basis) and a comparable control $\operatorname{diet}(0.0 \% \mathrm{CDG})$ within the same feeding trial.

\section{Descriptors of Diets and Response Variables}

Dietary concentrations of $\mathrm{CP}$ and $\mathrm{CP}$-fractions for corn-based CP (CCP) and non-corn-based CP (nonCCP) are presented in Table 1 . The difference $(\boldsymbol{\Delta})$ of individual nutrients was calculated by subtraction of the nutrient concentration in the control diet from that in the CDG diet. Therefore, a positive $\Delta$-value represents a greater concentration of a nutrient in the CDG diet than in the control diet (Table 1). Additional characteristics of the dietary compositions are in Hollmann et al. (2011).

Figure 1 shows the calculations for variables related to dietary $\mathrm{CP}$ fractions. We characterized CP fractions within dietary treatment as CCP (the sum of CP from dietary corn silage, corn grain, corn gluten meal, and hominy, among others) and non-CCP (the sum of CP from soybean meal, alfalfa, cottonseed, among others), expressed as a percentage of total dietary DM. Concen- trations of $\mathrm{CP}$ reported for individual feeds were used to calculate CCP and non-CCP. Book values for CP of corn grain $(9.4 \%$, dry basis), corn silage $(8.8 \%)$, ear corn (8.4\%), hominy (11.9\%), and CDG $(29.7 \%)$ were used (NRC, 2001) if these concentrations were not reported in the original articles. Each treatment mean had 11 associated independent variables describing dietary $\mathrm{CP}$ fractions (Figure 1): total CP (3 variables) for control and $\mathrm{CDG}$ diets and $\Delta-\mathrm{CP}$; non-CCP (3 variables) for control and CDG diets and $\Delta$-non-CCP; CCP (4 variables) in control diet and $\mathrm{CDG}$ diet, including $\mathrm{CP}$ from CDG (CCPwCDG) and without CP from CDG $(\mathbf{C C P w} / \mathbf{o C D G})$ and $\triangle$-CCP $(\mathbf{C C P w} / \mathbf{o C D G}$ minus $\mathrm{CCP}$ in control diet); and CCP (1 variable) from CDG (CCP-CDG). Descriptive statistics for these variables in the database are presented in Table 1.

Lactational performance variables included MY, milk true protein concentration and yield, and DMI in the control and CDG diets. If milk true protein was not provided in the original article, we assumed that $95.25 \%$ of milk CP was milk true protein (Verdi et al., 1987). Responses to dietary CDG were calculated as the difference in response of cows fed the control diet and the CDG diet, similar to the approach of Allen (2000). Additionally, the database was split into higher- and lower-producing cows using the approximate median (30.0 kg MY/cow per day) as the point of separation.

\section{Statistical Analysis}

Statistical analyses were similar to those described by Hollmann et al. (2011). General linear models were used for ANOVA (SAS version 9.1.3, SAS Institute, 2005). Lactational responses were regressed against one or more independent, fixed variables. Results were declared significant $(P<0.05)$, or as trends $(P<0.10)$ for single variables, or $P<0.15$ for interactions. The 


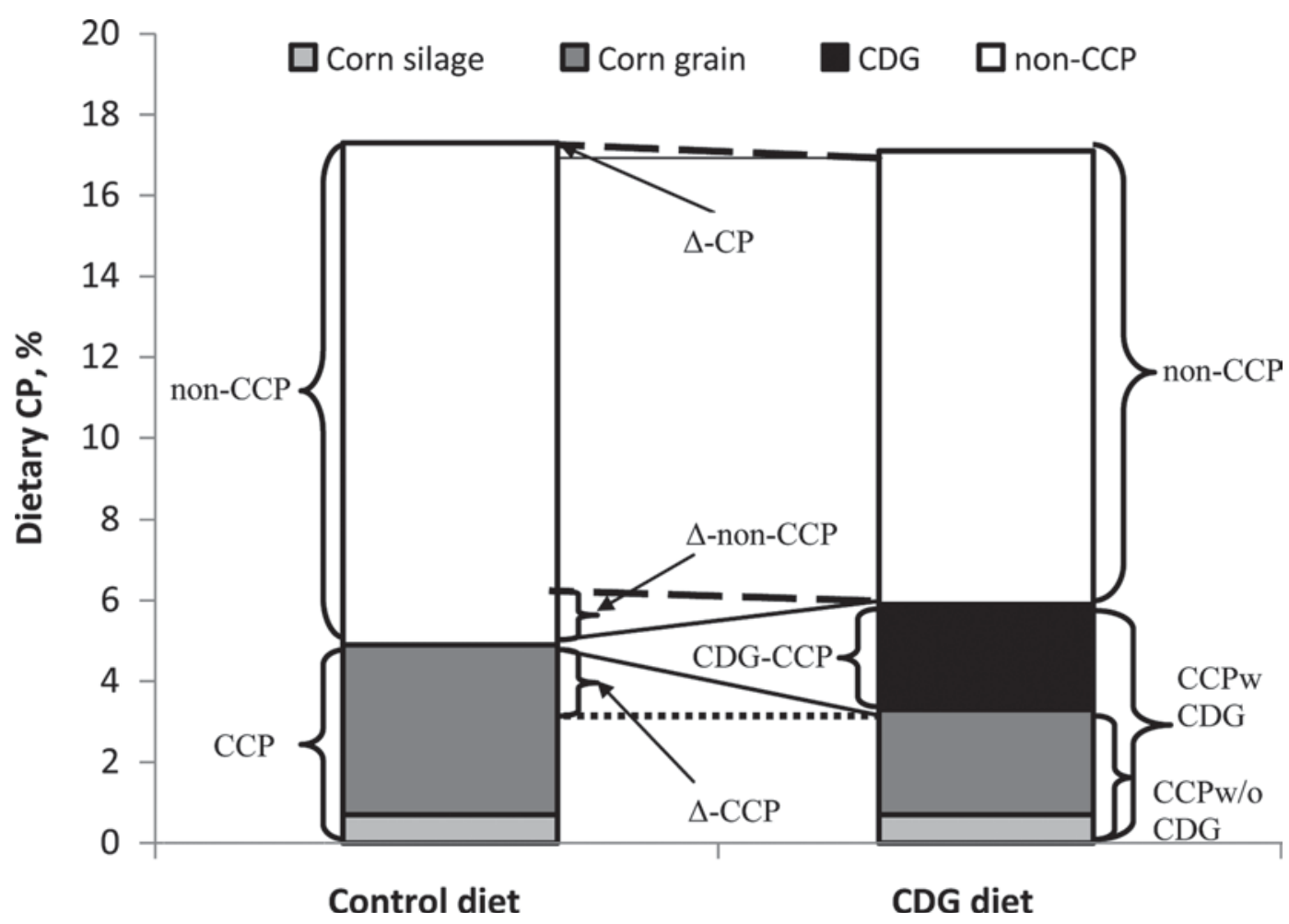

Figure 1. Overall characterization of $\mathrm{CP}$ fractions in control diet and corn distillers grains (CDG) diet in the database (\% of dietary DM; adapted from Clark and Armentano, 1997). Concentrations of dietary CP, DM basis, were for CP 17.1\% (control diet) and 17.3\% (CDG diet). Concentrations of dietary CP fractions were for corn-based CP (CCP): corn silage (0.7\%, 0.7\%), corn grain (4.2\%, 2.6\%), and CDG (CDG-CCP $0.0 \%, 2.6 \%$ ); and for non-corn-based CP (non-CCP; $12.2 \%, 11.4 \%$ ). Differences $(\Delta)$ in concentrations of CP-fractions between CDG diet and control diets are shown. $\mathrm{CCP}$ including $\mathrm{CDG}-\mathrm{CCP}=\mathrm{CCPwCDG}$; CCP excluding CDG-CCP $=\mathrm{CDGw} / \mathrm{oCDG}$.

Shapiro-Wilk test (SAS Version 9.1.3) was used to verify normal distribution of residuals. Outliers were identified based on Cook's distance (Cook, 1979) and omitted from the final database. No more than one outlier was removed from the database for any analysis.

\section{RESULTS}

Descriptive statistics of milk true protein concentration and yield, MY, and DMI in control and CDG diets, and their respective $\Delta$ are presented in Table 2 . Responses to non-CCP are depicted in Figures 2A to $2 \mathrm{C}$ and to $\mathrm{CCP}$ in Figures 3A to 3C.

\section{Milk Protein Concentration Response}

Milk true protein concentration response to dietary CDG was related negatively to dietary CDG concentration (Table $3 ; \mathrm{R}^{2}=0.15 ; P=0.02$ ). Milk true protein concentration resulting from control diets was not associated with the response of milk true protein concentration of cows fed diets with CDG.

The distribution of non-CCP concentration in the CDG treatment diet versus milk true protein concen- tration response to $\mathrm{CDG}$ is shown in Figure $2 \mathrm{~A}$. We divided the database at $6.5 \%$ non-CCP in the CDG diets, because the resulting regressions of the 2 databases intersected at $6.5 \%$ non-CCP (Figure 2A). Milk true protein concentration response was related positively to dietary non-CCP in a subset of the data that included means from CDG diets with less than $6.5 \%$ non-CCP $\left(\mathrm{R}^{2}=0.28 ; P_{\text {model }}<0.02 ; \mathrm{n}=28\right)$ and was not related to dietary non-CCP when non-CCP was greater than $6.5 \%\left(\mathrm{R}^{2}=0.01 ; P_{\text {model }}>0.10 ; \mathrm{n}=15 ;\right.$ Figure $\left.2 \mathrm{~A}\right) . \mathrm{In}$ further analysis, we divided the database with regard to MY of cows in the control diets into higher-producing cows ( $>30.0 \mathrm{~kg} /$ cow per day) and lower-producing cows $(<30.0 \mathrm{~kg} / \mathrm{cow}$ per day $)$. The relationship between response to $\mathrm{CDG}$ and concentration of non-CCP was similar for higher- and lower-producing cows. However, trials with lower-producing cows were associated with lower non-CCP concentrations in the CDG diet $(4.7 \%$ \pm 2.89 ; mean $\pm \mathrm{SD}$ ) than trials with higher-producing cows $(P<0.001 ; 7.8 \% \pm 3.06)$.

Concentrations of CCP in the control diets explained $19 \%$ of the variation in milk true protein concentration response $\left(P_{\text {model }}<0.01\right)$ and $\mathrm{CCPwCDG}$ in the CDG diets explained $22 \%$ of the variation (Table 3 ; 
Table 2. Descriptive statistics of lactational performance of cows fed control diets (Ctrl), corn distillers grains $(\mathrm{CDG})$ diets, and response to $\mathrm{CDG}$ inclusion $(\Delta ; \mathrm{CDG}$ minus $\mathrm{Ctrl})$ in experiments included in the statistical analyses of CDG on lactational performance $(\mathrm{n}=44)$

\begin{tabular}{llcccc}
\hline Variable & Diet & Mean & SD & Minimum & Maximum \\
\hline DMI, kg/cow per day & Ctrl & 23.1 & 2.12 & 19.4 & 29.4 \\
& CDG & 23.1 & 2.56 & 17.6 & 31.7 \\
Milk yield, kg/cow per day & $\Delta^{1}$ & 0.02 & 1.194 & -2.6 & 2.6 \\
& Ctrl & 31.6 & 5.83 & 24.3 & 44.6 \\
Milk true protein, \% & CDG & 32.0 & 6.49 & 23.3 & 46.4 \\
& $\Delta$ & 0.45 & 2.099 & -5.7 & 3.8 \\
Milk true protein yield, g/cow per day & Ctrl & 3.03 & 0.116 & 2.75 & 3.28 \\
& CDG & 2.96 & 0.150 & 2.57 & 3.19 \\
& $\Delta^{2}$ & -0.067 & 0.1199 & -0.42 & 0.18 \\
& CDG & 952 & 171 & 762 & 1,360 \\
& $\Delta$ & 948 & 215 & 641 & 1,430 \\
\end{tabular}

${ }^{1}$ Change in response of dependent variable to dietary inclusion of CDG. Positive value represents an increase in response to CDG.

${ }^{2}$ Change in milk true protein in percentage units.

$\left.P_{\text {model }}<0.01\right)$, whereas $\mathrm{CCPw} / \mathrm{oCDG}$ explained $16 \%$ of the variation (Figure $3 \mathrm{~A} ; P_{\text {model }}<0.01$ ). Increasing concentration of $\mathrm{CCP}$ related to a linear decrease in milk true protein concentration response. Response in milk true protein concentration to dietary CDG inclusion was not affected by the $\mathrm{CP}$ concentration of the control or the CDG diets, or by $\Delta-\mathrm{CP}$ (difference of CP concentration in the CDG diet minus control diet) in the current analysis.

\section{Milk Protein Yield Responses}

Concentrations of the defined CP-fractions also explained variation in milk protein yield response to CDG. Concentration of $\mathrm{CCPw} / \mathrm{oCDG}$ accounted for $48 \%$ of the variation in milk protein yield (Table $3 ; P$ $<0.001)$. Highest response in milk protein yield was with $3.8 \% \mathrm{CCPw} / \mathrm{oCDG}\left(P_{\text {quadratic }}<0.01\right)$. Moreover, response was negative, when concentration of $\mathrm{CCPw} /$ oCDG was greater than $5.5 \%$, but positive for lower concentrations (Figure 3B). This response occurred in lower-producing cows $\left(\mathrm{R}^{2}=0.33 ; P_{\text {model }}<0.01 ; \mathrm{n}=\right.$ $21)$ and higher-producing cows $\left(\mathrm{R}^{2}=0.63 ; P_{\text {model }}<\right.$ $0.001 ; \mathrm{n}=23)$. However, less variation in milk true protein yield was explained in the full database, when CCPwCDG instead of CCPw/oCDG was evaluated as the independent variable (Table $3 ; P_{\text {model }}=0.02$ ). Thus, the CP from corn products other than CDG was related more to milk true protein yield response than was the $\mathrm{CP}$ fraction from all corn products including CDG. Furthermore, concentration of non-CCP in the CDG diets was related to milk true protein yield response (Table $3 ; \mathrm{R}^{2}=0.37 ; P_{\text {model }}<0.001$ ). Response peaked ( $45 \mathrm{~g} /$ cow per day) with $8.8 \%$ non-CCP, but was negative when concentration of non-CCP was lower than 4.7 or greater than $12.9 \%$ (Figure 2B; $P_{\text {quadratic }}<$ $0.001)$. This response to non-CCP was pronounced in lower-producing cows $\left(\mathrm{R}^{2}=0.41 ; P_{\text {model }}=0.008 ; \mathrm{n}=\right.$ $21)$, but not in higher-producing cows $\left(P_{\text {model }}>0.10\right.$; $\mathrm{n}=22$ ). In the full database, non-CCP concentration in the CDG diets was not evenly distributed across the range of milk true protein yields. In particular, nonCCP concentrations below $4.0 \%$ were associated with the lowest yields of milk true protein/cow per day $(\mathrm{n}=$ 10; 791 to $800 \mathrm{~g}$ /cow per day, range). Thus, we created 2 restricted, but balanced databases, where 1) means with milk true protein yield of greater than $1,100 \mathrm{~g} /$ cow per day, or 2) means with less than $4.0 \%$ non-CCP (low), were removed. Milk protein yield response to CDG was similar to that of the full database in the first restricted database (true protein yields greater than $1,100 \mathrm{~g} /$ cow per day removed from analysis; $\mathrm{R}^{2}=0.34$; $\left.P_{\text {model }}<0.001 ; \mathrm{n}=36\right)$. However, non-CCP was not related to milk true protein yield response when means with low non-CCP concentration were eliminated $(\mathrm{n}=$ 33). Corn-based CP in the control diet was associated with the milk true protein yield response (Table $3 ; \mathrm{R}^{2}=$ $\left.0.35 ; P_{\text {model }}<0.001\right)$. Milk true protein yield response peaked when CDG was substituted in diets with $4.8 \%$ CCP $\left(P_{\text {quadratic }}=0.03\right)$ and a negative yield response to $\mathrm{CDG}$ was related to more than $6.4 \% \mathrm{CCP}$ in the control diet.

Dietary concentration of CDG was not associated with response in milk true protein yield (Table 3). However, milk true protein yield of the control diet was related to milk true protein yield response to CDG (Figure $\left.4 ; \mathrm{R}^{2}=0.28 ; P_{\text {model }}<0.001 ; \mathrm{n}=43\right)$. Experiments in which control cows produced more than $884 \mathrm{~g}$ of true milk protein/cow per day had a positive milk protein yield response to dietary CDG inclusion, whereas a true 
HOLLMANN ET AL.
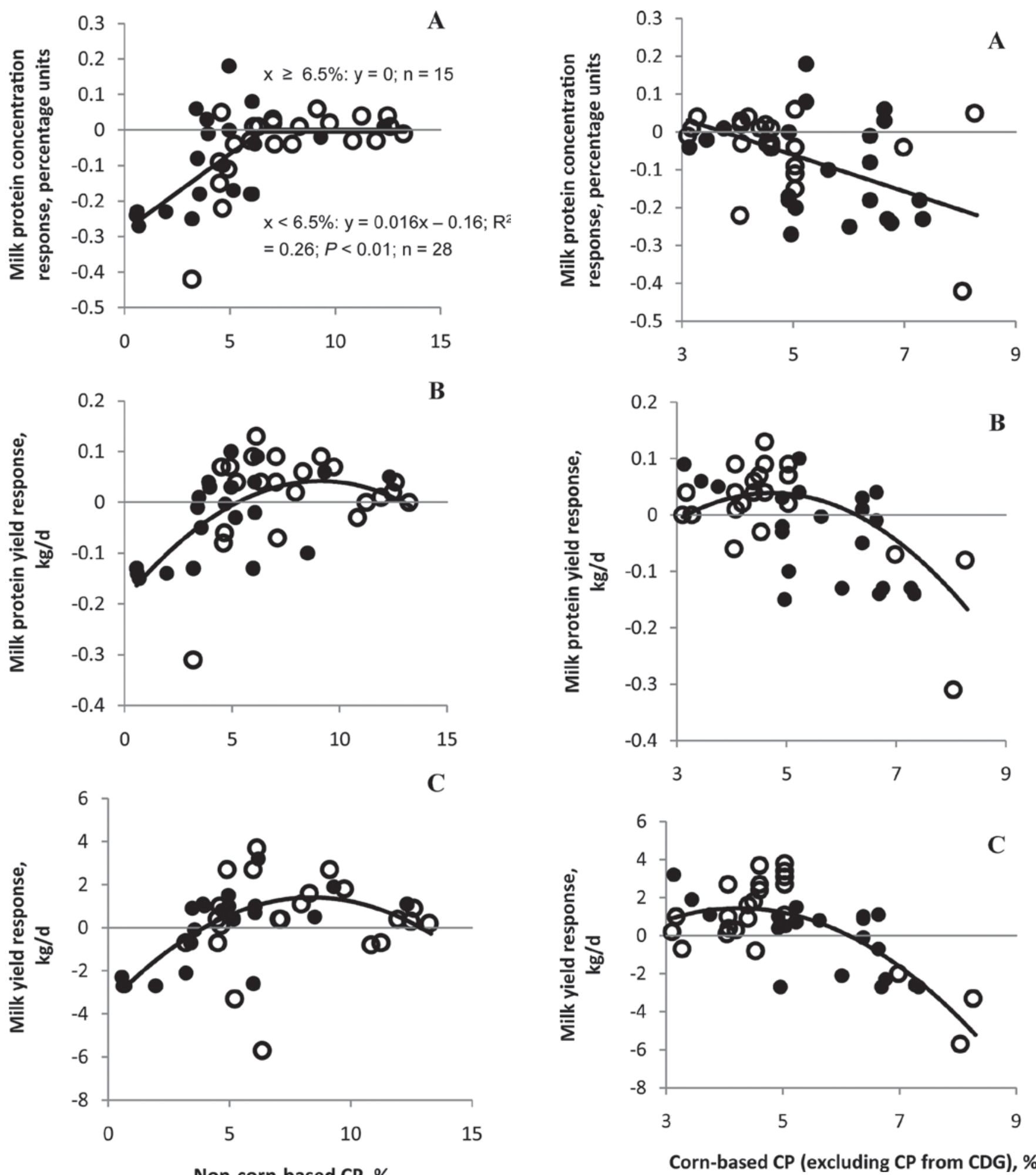

Non-corn-based CP, \%

Figure 2. Responses in milk true protein concentration (A), milk true protein yield (B), and milk yield (C) to dietary corn distillers grains compared with the control related to concentration of non-cornbased $\mathrm{CP}$ in total dietary DM in trials with lower-producing cows (solid circles ; $<30.0 \mathrm{~kg}$ milk yield/cow per day) and higher-producing cows (open circles; $>30.0 \mathrm{~kg}$ milk yield/cow per day).

Figure 3. Responses in milk protein concentration (A), milk protein yield (B), and milk yield (C) to dietary corn distillers grains compared with the control related to corn-based CP excluding CP from corn distillers grains (CDG)] in total dietary DM in trials with lower-producing cows (solid circles; $<30.0 \mathrm{~kg}$ milk yield/cow per day) and higher-producing cows (open circles; $>30.0 \mathrm{~kg}$ milk yield/cow per day). 
Table 3. Lactational responses to dietary corn distillers grains (CDG) based on concentration of dietary CP fractions and DMI

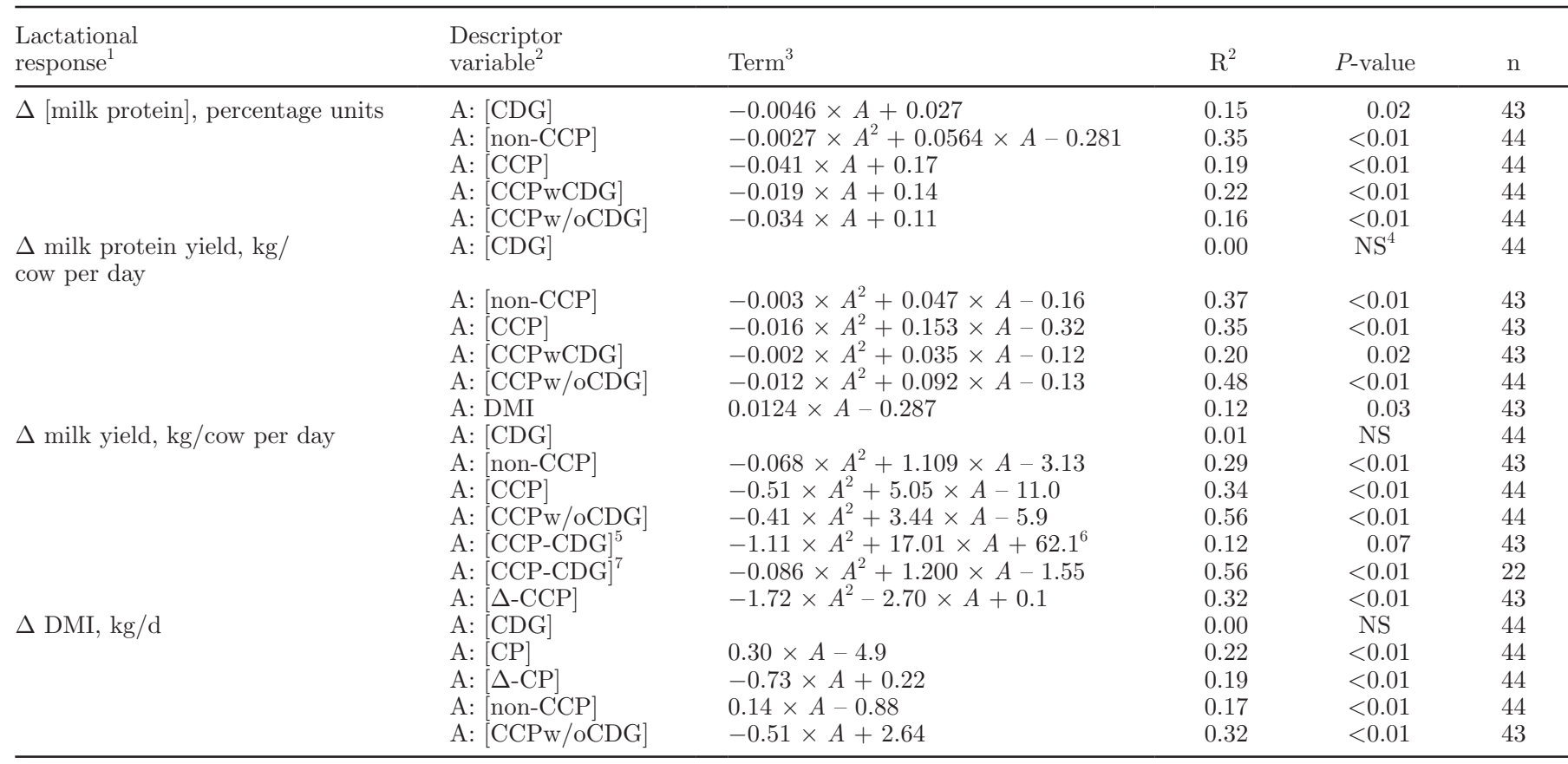

${ }^{1}$ Lactational response $(\Delta$ response $)=$ CDG diet mean minus control mean.

${ }^{2}[\mathrm{X}]=$ dietary concentration of $\mathrm{X}: \Delta=$ difference of respective concentration in percentage units, $\mathrm{CDG}$ minus control diet; non-CCP $=\mathrm{CP}$ from non-corn sources; $\mathrm{CCP}=\mathrm{CP}$ from corn sources in control diet; $\mathrm{CCPwCDG}=\mathrm{CP}$ from corn sources including $\mathrm{CDG}$ in treatment diet; $\mathrm{CCP}$ / $\mathrm{oCDG}=\mathrm{CP}$ from corn sources excluding $\mathrm{CDG}$ in treatment diet; CCP-CDG = CCP from CDG; all concentrations based on total DM; DMI $=\mathrm{DMI}$ of control diet.

${ }^{3} A=$ descriptor variable.

${ }^{4}$ Nonsignificant $(P>0.10)$.

${ }^{5}$ If no CP concentration for CDG was given in the original paper, mean CP concentration (NRC, 2001) was used to calculate CCP-CDG.

${ }^{6}$ Response variable transformed: $(\mathrm{X}+10)^{2}$.

${ }^{7}$ Included only CCP-CDG from studies with known CP concentration in CDG.

protein yield of less than $884 \mathrm{~g} /$ cow per day for cows fed the control diet was related to negative milk true protein yield response. Response peaked when control cows produced $1,170 \mathrm{~g}$ of milk true protein/d $\left(P_{\text {quadratic }}\right.$ $=0.04$ ). In addition, milk true protein yield response was related to DMI of cows fed the control diet (Table $\left.3 ; \mathrm{R}^{2}=0.12 ; P_{\text {model }}=0.03\right)$. Greater DMI was associated with a greater milk protein yield response that was positive when cows had DMI greater than $23.1 \mathrm{~kg} /$ cow per day.

\section{Milk Yield Response}

The concentration of CCPw/oCDG explained $56 \%$ of the variation in MY response to $\mathrm{CDG}$ (Table $3 ; P_{\text {model }}<$ $0.001)$. Response was greatest (1.5 kg MY/cow per day), when CDG diets had 4.3\% CCPw/oCDG (Figure 3C; $\left.P_{\text {quadratic }}<0.001\right)$. However, $\mathrm{CCPw} / \mathrm{oCDG}$ concentrations greater than $6.1 \%$ were associated with a negative MY response. This response differed for higher- versus lower-producing cows (breakpoint of $30.0 \mathrm{~kg} \mathrm{MY} / \mathrm{cow}$ per day). Response in MY of higher-producing cows was related to $\mathrm{CCPw} / \mathrm{oCDG}$ in a similar fashion as the full database (Figure 3C; $\mathrm{R}^{2}=0.70 ; P_{\text {model }}<0.001 ; \mathrm{n}$ $=23)$; MY response increased linearly from -0.2 to 2.6 $\mathrm{kg} / \mathrm{cow}$ per day, as CCPw/oCDG increased from 3.1 to $5.0 \%$ of dietary DM $\left(\mathrm{R}^{2}=0.34 ; P_{\text {model }}=0.004 ; \mathrm{n}=\right.$ $20)$. However, response was less than $-2.0 \mathrm{~kg} /$ cow per day when CCPw/oCDG was greater than $6.5 \%(\mathrm{n}=3)$. In contrast, MY response decreased linearly as $\mathrm{CCPw} /$ oCDG increased in lower-producing cows. Furthermore, replacing 0.8 percentage units of $\mathrm{CCP}$ in the control diet with CDG $(\Delta$-CCP $=-0.8)$ was associated with the greatest MY response (Table $3 ; \mathrm{R}^{2}=0.32 ; P_{\text {model }}$ $\left.<0.001 ; P_{\text {quadratic }}<0.001\right)$. Yet, response to CDG was negative when more than 1.6 or less than 0.0 percentage units of CCP were replaced in the CDG diet. This was based on a strong association of $\triangle$-CCP and MY response in higher-producing cows $\left(\mathrm{R}^{2}=0.63 ; P_{\text {model }}<\right.$ $\left.0.001 ; P_{\text {quadratic }}<0.001 ; \mathrm{n}=22\right)$, whereas $\Delta$-CCP was not related to MY response in lower-producing cows.

Concentration of CCP in the control diets was associated with MY response to CDG (Table $3 ; \mathrm{R}^{2}=0.34$; $\left.P_{\text {model }}<0.001\right)$. Response of cows was positive when 


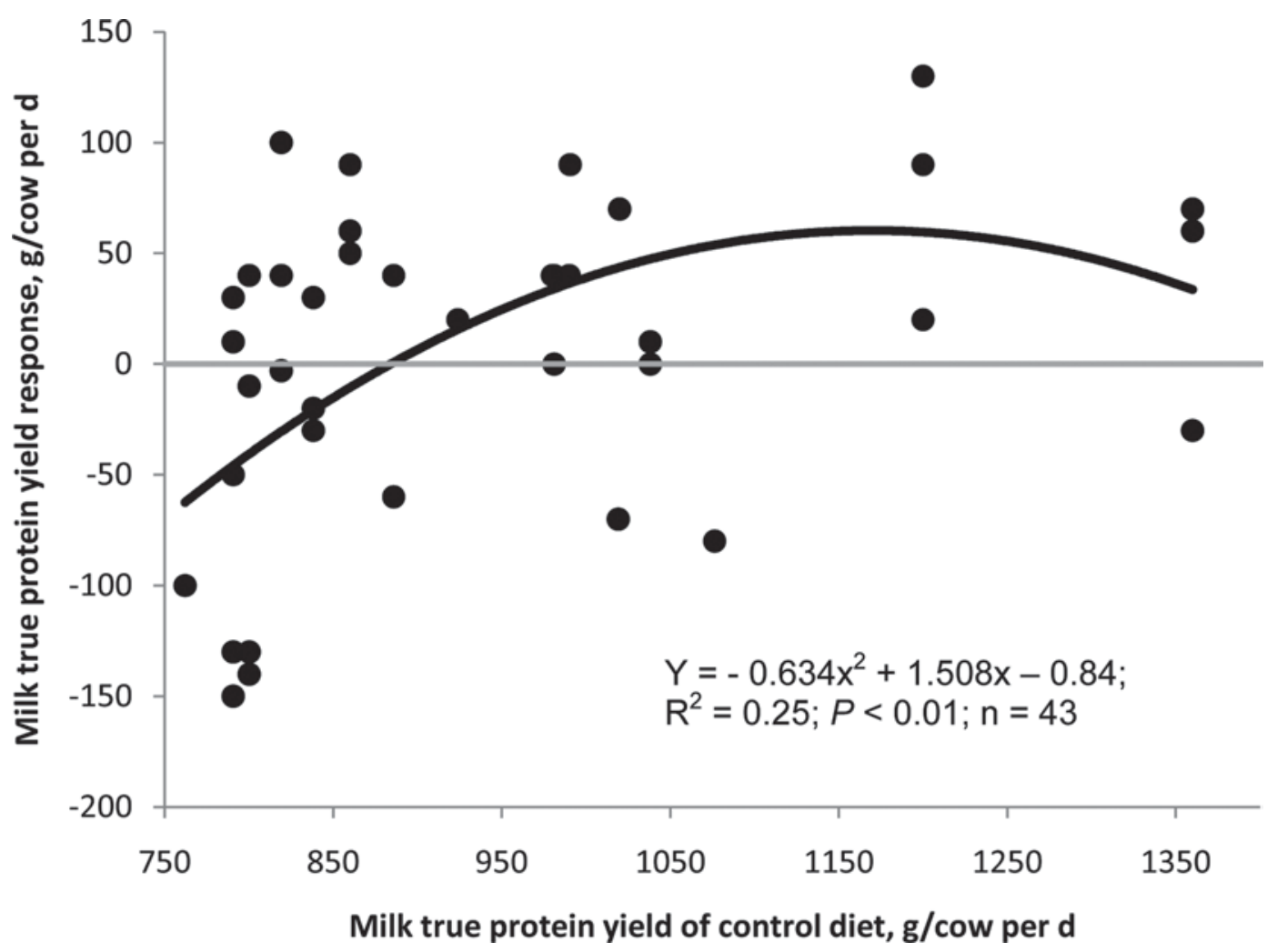

Figure 4. Milk true protein yield response [corn distillers grains (CDG) diet mean minus control diet mean within experiment] to dietary CDG related to milk true protein yield in cows fed the control diet.

fed control diets containing less than $6.7 \% \mathrm{CCP}$ and peaked at $5.0 \%\left(P_{\text {quadratic }}<0.001\right)$, whereas concentration greater than $6.7 \% \mathrm{CCP}$ was related to a negative $\mathrm{MY}$ response to CDG. Overall, CCP in control diets explained less variation in MY response than did $\mathrm{CCPw} /$ oCDG; however, shapes of the responses were similar.

Response in MY was related to the concentration of non-CCP in the CDG diet (Table $3 ; \mathrm{R}^{2}=0.29 ; P_{\text {model }}$ $<0.001)$. Response in MY increased, as concentration of non-CCP increased to $8.2 \%$ of the total dietary DM. Concentrations greater than $8.2 \%$ non-CCP were associated with a decreasing MY response $\left(P_{\text {quadratic }}<\right.$ 0.001). Response was negative when non-CCP was less than $3.9 \%$ or greater than $12.5 \%$ of dietary DM (Figure $2 \mathrm{C}$ ). This overall response was apparently highly influenced by a quadratic association of non-CCP and $\mathrm{MY}$ response in lower-producing cows $\left(\mathrm{R}^{2}=0.55 ; P_{\text {model }}\right.$ $\left.<0.001 ; P_{\text {quadratic }}=0.02 ; \mathrm{n}=21\right)$. Non-CCP was not related to MY response in higher-producing cows $(\mathrm{n}=$ 22).

Dietary concentration of CCP-CDG accounted for $56 \%$ of the variation in MY response to CDG diet (Table $\left.3 ; P_{\text {model }}<0.001\right)$ in studies that reported CCP-CDG. The greatest response was associated with treatment diets containing 6.9\% CCP-CDG. Adding the additional treatment means with calculated CCP-CDG explained $12 \%$ of the variation (Table $3 ; P=0.07$ ). Variation in $\mathrm{CP}$ concentration was greater for CDG $(30.8 \pm 3.48$, mean \pm SD; 25.4 to $39.5 \%$ of dietary DM, range) than for any other corn-based ingredients used in diets of the experiments in the current database. This may explain the difference in accuracy between the actual CCPCDG and the calculated concentration based on NRC (2001) mean CP concentration for CDG.

\section{DMI Response}

Dry matter intake response to CDG increased linearly with increasing dietary CP concentration of control diets (Table $3 ; \mathrm{R}^{2}=0.22 ; P_{\text {model }}<0.01$ ). A concentration of $\mathrm{CP}$ greater than $16.5 \%$, dry basis, was related to an increase in DMI of cows fed CDG diets, whereas a lower concentration was associated with a negative DMI response. This DMI response was more pronounced in lower- $\left(\mathrm{R}^{2}=0.39 ; P_{\text {model }}<0.01\right)$ than in higherproducing cows $\left(\mathrm{R}^{2}=0.13 ; P_{\text {model }}=0.03\right)$. In further evaluation, $\Delta$-CP of 0.3 or more percentage units was related to a positive response in DMI (Table $3 ; \mathrm{R}^{2}=$ $\left.0.19 ; P_{\text {model }}<0.01\right)$. A $\Delta$-CP of less than 0.3 percentage units was related to a negative DMI response. 
The concentration of CCPw/oCDG explained $32 \%$ of the variation in DMI response (Table $3 ; P_{\text {model }}<$ 0.001). Response in DMI was positive when $\mathrm{CCPw} /$ oCDG contributed less than $5.2 \%$ to the total dietary $\mathrm{DM}$, but negative for $5.2 \%$ or more CCPw/oCDG. Response in DMI was associated strongly with $\mathrm{CCPw} /$ oCDG $\left(\mathrm{R}^{2}=0.66 ; P_{\text {model }}<0.001 ; \mathrm{n}=21\right)$ in lower-, but not in higher-producing cows. Likewise, a non-CCP concentration greater than $6.1 \%$ was associated with a positive DMI response to CDG, whereas a lower nonCCP concentration was related to a negative response (Table $3 ; \mathrm{R}^{2}=0.17 ; P_{\text {model }}<0.01$ ). This response was more pronounced in lower-producing cows $\left(\mathrm{R}^{2}=0.37\right.$; $\left.P_{\text {model }}<0.01 ; \mathrm{n}=21\right)$ than in higher-producing cows $\left(\mathrm{R}^{2}=0.15 ; P_{\text {model }}=0.07 ; \mathrm{n}=23\right)$.

\section{DISCUSSION}

Responses in yields of milk and milk true protein to CDG were not related to dietary concentration of CDG or CP. Therefore, based on the database used in this meta-analysis, no specific dietary concentration of CDG that maximizes yields of milk and milk true protein exists. However, MY response to dietary CDG was related to the fraction of corn-based protein in the diet and to the level of MY of cows fed control diets. Increasing concentration of non-CCP was associated with greater responses for yields of milk and true protein, and greater milk true protein concentration, with maximum responses at $8.2 \%, 8.8 \%$, and greater than $6.5 \%$ non-CCP, respectively. Maintaining milk and milk true protein yields of cows fed CDG diets requires that at least $5 \%$ of dietary DM originates from non-CCP (Figures 2B and $\mathrm{C}$ ). These observations are consistent with lysine as the limiting amino acid for MY; increasing lysine intake beyond this amount does not affect milk true protein concentration and yield (NRC, 2001). More recently, Vyas and Erdman (2009) concluded that a sufficient concentration of dietary lysine must be provided to maximize milk true protein yield. With the current database, milk and protein yields were maximized with $8.5 \%$ non-CCP. Yet, concentrations greater than $6.5 \%$ non-CCP generally sustained milk and protein yields for cows fed CDG diets.

Most of the current results and interpretation are based on treatment means of less than $30.0 \mathrm{~kg}$ MY/ cow per day for the control diet. This binominal classification was based on the MY of cows fed the control diet; thus, deficiency in one or more AA in the control diet could have contributed to this classification. Possibly, protein quality in control diets was limiting MY in these experiments. Inclusion of CDG could exacerbate the dietary protein limitations of lower-producing cows. Alternatively, lactational yield responses were a consequence of lower DMI response as concentration of dietary non-CCP decreased and CCP increased (Table $3)$. As a result, inclusion of CDG limited lactational performance of lower-producing cows further. However, protein quality was most likely not the sole factor influencing lactational responses of cows to CDG in the current analyses. Diet fermentability, such as influenced by starch concentration and fermentability, also was associated with lactational responses to CDG (Hollmann et al., 2011). Moreover, availability of ruminally available $\mathrm{N}$ and peptides must complement the needs of ruminal microorganisms for carbohydrate digestion at any given time to maximize digestion efficiency (Firkins et al., 2007). In our analysis, we were not able to integrate dietary protein, carbohydrate, and lipid concentrations and relate them with lactational responses due to the limited number of treatment means in the database and description of diets. Nonetheless, the presumed presence of diets that likely limit MY in the current database illustrate the constraints of relatively poorer dietary protein quality (e.g., lysine deficient) in CDGcontaining treatment diets.

Recommended dietary concentrations of CP for lactating cows range from 13.5 to $18 \%$, as influenced by MY, stage of lactation, live BW, DMI, degradability of the CP, and available feedstuffs (NRC, 2001). This relates to 5 to $9.5 \% \mathrm{CCP}$, assuming that $8.5 \%$ of $\mathrm{DM}$ should be non-CCP and that overfeeding of $\mathrm{N}$ should be avoided to decrease $\mathrm{N}$ wastage and environmental concerns. Supplying $20 \%$ of dietary DM as CDG equates to about $6 \%$ CCP. This would limit the amounts of corn silage, corn grain, and other corn products that can be included in the diet without overfeeding $\mathrm{N}$, given that diets should contain at least $6.5 \%$ non-CCP.

Concentrations greater than $11 \%$ non-CCP decreased lactational responses slightly, but diets with more than $11 \%$ non-CCP, in addition to CCPwCDG, will oversupply dietary $\mathrm{CP}$. Once a ration is balanced for non-CCP and $\mathrm{CP}$, the concentration of $\mathrm{CCP}$ is fixed. Non-CCP includes essential AA that may be in limiting concentrations in CCP (e.g., lysine), and dietary non-CCP and CCP concentrations were inversely related in the current database. Thus, the findings in the current analysis relating $\mathrm{CCP}$ to $\mathrm{MY}$ and protein yield responses to CDG are secondary to non-CCP concentration, because treatment diets (e.g., those with added CDG) in the database were generally balanced for $\mathrm{CP}$.

Dietary concentration of $\mathrm{CCPw} / \mathrm{oCDG}$ correlated negatively with milk true protein concentration and yield, and MY responses. Change in milk protein yield was negative when diets contained more than $5.5 \%$ $\mathrm{CCPw} / \mathrm{oCDG}$. When providing recommendations for 
feeding CDG, sufficient non-CCP (e.g., 6.5\% or more of dietary DM) should be supplied, with the remaining $\mathrm{CP}$ provided as $\mathrm{CCPwCDG}$. This recommendation is contrary to the current trend of increasing the concentrations of corn products such as corn silage and corn grain in Midwestern US rations. If, for economical or availability reasons, less non-CCP is provided in a diet containing CDG, supplementation of lysine that escapes ruminal degradation may improve milk protein yield (Nichols et al., 1998).

Excluding the CP from CDG in the calculation of $\mathrm{CCP}$ concentration in the diet explained the variation in lactational responses to CDG better than including CP from CDG. Crude protein concentration (\% of dietary DM) in CDG varied more across experiments in the current database and between batches from corn ethanol plants (Rausch and Belyea, 2006) than the CP concentration of other corn products [e.g., corn silage \pm 1.2 percentage units $( \pm \mathrm{SD})$, or dry corn \pm 1.3 (NRC, 2001)]. Moreover, some portions of the CCP in CDG may have been heat-damaged in some experiments (Powers et al., 1995; Kleinschmit et al., 2006). Thus, the variation in available $\mathrm{CP}$ and, specifically, availability of lysine in CDG, is potentially even greater than the variation in CP (Powers et al., 1995; Schingoethe et al., 2009).

\section{CONCLUSIONS}

Responses in MY and milk true protein yield and concentration to dietary CDG inclusion were affected by dietary non-CCP (and consequently CCP) concentration. Based on our meta-analysis, lactation diets with CDG should contain at least $6.5 \%$ non-CCP to maintain MY and milk true protein yield; however, greatest MY and true milk protein yield responses to CDG were associated with diets containing approximately $8.5 \%$ non-CCP.

\section{REFERENCES}

Allen, M. S. 2000. Effects of diet on short-term regulation of feed intake by lactating dairy cattle. J. Dairy Sci. 83:1598-1624.

Clark, J. H. 1975. Lactational responses to postruminal administration of proteins and amino acids. J. Dairy Sci. 58:1178-1197.

Clark, P. W., and L. E. Armentano. 1997. Replacement of alfalfa neutral detergent fiber with a combination of nonforage fiber sources. J. Dairy Sci. 80:675-680.

Cook, R. D. 1979. Influential observations in linear regression. J. Am. Stat. Assoc. 74:169-174.

Dado, R. G. 1999. Nutritional benefits of specialty corn grain hybrids in dairy diets. J. Anim. Sci. 77:197-207.

Firkins, J. L., L. L. Berger, G. C. Fahey Jr., and N. R. Merchen. 1984. Ruminal nitrogen degradability and escape of wet and dry distillers grains and wet and dry corn gluten feeds. J. Dairy Sci. 67:1936-1944

Firkins, J. L., Z. Yu, and M. Morrison. 2007. Ruminal nitrogen metabolism: Perspectives for integration of microbiology and nutrition for dairy. J. Dairy Sci. 90(E. Suppl.):E1-E16.

Hollmann, M., M. S. Allen, and D. K. Beede. 2011. Diet fermentability influences lactational performance responses to corn distillers grains: A meta-analysis. J. Dairy Sci. 94:2007-2021.

Kleinschmit, D. H., D. J. Schingoethe, K. F. Kalscheur, and A. R. Hippen. 2006. Evaluation of various sources of corn dried distillers grains plus solubles for lactating dairy cows. J. Dairy Sci. 89:4784-4794.

Nichols, J. R., D. J. Schingoethe, H. A. Maiga, M. J. Brouk, and M. S. Piepenbrink. 1998. Evaluation of corn distillers grains and ruminally protected lysine and methionine for lactating dairy cows. J. Dairy Sci. 81:482-491.

NRC. 2001. Nutrient Requirements of Dairy Cattle. 7th rev. ed. Natl. Acad. Sci., Washington, DC.

Powers, W. J., H. H. Van Horn, B. Harris Jr., and C. J. Wilcox. 1995. Effects of variable sources of distillers grains plus solubles on milk yield and composition. J. Dairy Sci. 78:388-396.

Rausch, K. D., and R. L. Belyea. 2006. The future of coproducts from corn processing. Appl. Biochem. Biotechnol. 128:47-86.

SAS Institute. 2005. SAS User's Guide: Statistics. Version 9.1.3. SAS Inst. Inc., Cary, NC.

Schingoethe, D. J., K. F. Kalscheur, A. R. Hippen, and A. D. Garcia. 2009. Invited review: The use of distillers products in dairy cattle diets. J. Dairy Sci. 92:5802-5813.

Verdi, R. J., D. M. Barbano, M. E. Dellavalle, and G. F. Senyk. 1987. Variability in true protein, casein, nonprotein nitrogen, and proteolysis in high and low somatic cell milks. J. Dairy Sci. 70:230242.

Vyas, D., and R. A. Erdman. 2009. Meta-analysis of milk protein yield response to lysine and methionine supplementation. J. Dairy Sci. 92:5011-5018. 